\title{
The Attitudes and Awareness of the Teacher Candidates about Cultural Heritage
}

\author{
Suat Polat ${ }^{1, *}$ \\ ${ }^{1}$ Faculty of Education, Department of Turkish and Social Sciences Education, Ağrı İbrahim Çeçen University, Ağrı, \\ Turkey \\ *Correspondence: Faculty of Education, Department of Turkish and Social Sciences Education, Ağrı İbrahim Çeçen \\ University, Ağr1, Turkey. E-mail: suat.polat04@yandex.com
}

This study was carried out by Ağrı İbrahim Çeçen University, Scientific Researches Project Unit in Supported by project number EF. 17002.

Received: August 8, 2018

Accepted: August 29, $2018 \quad$ Online Published: September 27, 2018

doi:10.5430/wje.v8n5p49

URL: https://doi.org/10.5430/wje.v8n5p49

\begin{abstract}
The purpose of this study is to determine of the teacher candidates' attitudes and awareness levels towards cultural heritage and to ensure that the teacher candidates gain awareness of cultural heritage. The research is based on an experimental model from quantitative research approaches and the population consists of teacher candidates who study in Faculty of Education at Ağrı İbrahim Çeçen University. Simple random sampling method was used to determine sample of the study. The data of the study was gathered with Personal Information Form and the Cultural Heritage Attitude Scale developed by Akbaba (2014). SPSS 22 program is used in the analysis of the data. According to the results obtained, it is determined that gender, class and education status of the father are not effective in attitudes and awareness towards cultural heritage, whereas the undergraduate program and education of mother play an effective role. It has been determined that the educational trip has positively affected the transfer of cultural heritage, consciousness of cultural heritage and cultural heritage for the society.
\end{abstract}

Keywords: cultural assets, teacher candidates, awareness, attitude

\section{Introduction}

Culture is all the products that distinguish a society or a people from others in terms of their way of feeling, thinking, living, and that created in both the material and the spiritual area. It is all the works of arts and frame of mind specific to a society or a people. All kinds of tools, the techniques, thoughts, skills, beliefs, traditional, religious, social, political order and institutions, thoughts, perceptions, attitudes behaviors and lifestyle to get basic needs like food, the clothing, residence, shelter constitute the cultural assets (www.tdk.gov.tr). Culture is formed by the dynamics of the society which forms the culture in a natural way over time.

Cultural assets are defined as the portable or premises works that have the characteristics of documents that inform us about the old cultures below or above the ground or underwater (Asatekin, 2004, 22). Our country has hosted many civilizations throughout the history, and a vast scale of cultural assets below and above the ground and underwater have been inherited to us from these civilizations. These works are the witness of important characteristics of the era they belong to like social structure, culture, art, development level, economy. Cultural and natural assets are our basic foundation with which we enlighten and shape our future.

Our cultural and natural assets are of great importance for us because many works completed in the past are religious, national or ideological symbols, which makes them important and worth preserving (Ahunbay, 2009, 8). The past is the first point we apply when we face a difficulty. The attitudes that adopted in similar situations, previous experiences are the first places we apply (Altınörs, 2005, 41). Also belonging instinct is another reason that makes our past worthy. However, the most important reason that makes our past valuable is the desire to give direction to our future. Churchill emphasized the importance of knowing how history will give the right direction to the future with the words "The farther back you can look, the farther forward you are likely to see". Moreover, the fact that the 
past is strong and rooted means that progression will be easier and faster. Anatolia has a very special value with its strong roots extending deep, and whose each square meter smells history is worth protecting.

Such a rich country in terms of cultural and natural assets also obliges to have a conservation culture. Because it is impossible to prevent the destruction of cultural and natural assets. Like every being, they also have an absolute end. What is more dangerous, however, is that these riches are erased from people's minds. These natural and historical riches become meaningful to individuals who have the ability to live in harmony with those riches and who know, recognize and protect them. Cultural and natural assets can gain value only by the individuals who are excited about them. In this respect, knowledge of cultural and natural assets should be one of the important elements of conservation culture and conservation education (Karip, 2016).

We can say that there is a controversy between our potential to have cultural and natural assets and our conservation efforts. We can say that we are lacking in creating a social consciousness in terms of conservation (Bilgili, 2010). Our country has made important political breakthroughs by signing several declarations on the national and international platform for the protection of cultural and natural assets (Asatekin, 2005). But we can say that our country is lacking in the formation of a conservation culture by spreading the conservation consciousness to the social base. For this reason, the studies carried out in this area should be considered together with the social, cultural and educational dimensions along with the political and economic basis (Altınörs, 2010). It is emphasized in various studies in the literature that education is important for cultural heritage and people can be informed through cultural education in school. (Copeland, 2006; Alkış ve Oğuzoğlu, 2005; Curtis and Seymour, 2004; Henson, Stone and Corbishley, 2004; Hunter, 1988; Patric, 1988). Informing the people about the education of cultural and natural assets in our country is left to the university stage or even to the master's degree education. It is a relatively late time for internalizing the importance of cultural and natural assets to make them an integral part of their identity after the basic personality qualities of individuals who form the society have been determined and finalized (Asatekin, 2005, p.51). Therefore, children should be aware of the historical environmental awareness and 'conservation awareness' should be established with appropriate materials and activities in primary education period and even pre-school period.

\section{Material and Method}

\subsection{Method}

The study was designed based on experimental model from quantitative research methods. Experimental surveys are research aiming to find out what kind of effects the differences that the researcher has created have on the dependent variable. The purpose of such studies is to test the cause-effect relationship between variables (Büyüköztürk, 2014, 195). Experimental designs aim to reveal what occurs and is acceptable as a result of testing new things (Robson, 1993/2015, 113). To summarize the experimental design, it is the research that tests the effect of independent variables on the dependent variable in a controlled and checked environment (Sönmez and Alacapınar, 2014, 51).

\subsection{Population and Sample}

The population of the research is formed by the teacher candidates who are studying in Faculty of Education, İbrahim Chechen University of Ağrı (Departments of Social Sciences Teaching, Turkish Language Teaching, Classroom Teaching, Pre-school, Art Teaching, and Music Teaching). Since the research was based trips for education, the entire population could not be reached and the sampling was preferred. When selecting of the sample, stratified sampling among simple random sampling methods was used, and 25 students were selected on a volunteer basis.

In this sampling method, all the units in the population should belong to one and only one stratum, no population unit should be excluded. In the stratified sampling, the population is divided into small groups in which the change should be homogeneous inter-stratum as far as possible and it should be heterogeneous between the strata, and adequate sampling from each group is selected and included in the research (Büyüköztürk, 2014, 86). In this study, the programs including subjects about the cultural assets are determined and 25 students from each program are selected randomly and included in the study.

\subsection{Data Collection Tools}

The data of the study was collected with Personal Information Form developed by the researchers and Cultural Heritage Attitude Scale developed by Akbaba (2014). Reliability calculations of each item on the cultural heritage attitude scale which consists of 32 items and 3 sub-dimensions - cultural heritage for society, sensitiveness towards cultural heritage and transfer of cultural heritage- were done and are indicated on Table 1. 
Table 1. Reliability Data of Cultural Heritage Attitude Scale

\begin{tabular}{|c|c|c|c|c|c|}
\hline \multicolumn{3}{|r|}{ Items } & F1 & $\mathbf{F 2}$ & F3 \\
\hline \multirow{9}{*}{ 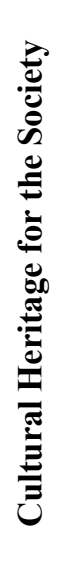 } & M1 & Cultural heritage does not contribute to the unity of societies. & .72 & & \\
\hline & M2 & I do not think that cultural heritage gives information about past experiences. & .72 & & \\
\hline & M3 & I do not believe that cultural heritage is a part of society. & .71 & & \\
\hline & M4 & I think that cultural heritage is not important to communities. & .70 & & \\
\hline & M5 & I do not think that cultural heritage is a sign of social identity. & 68 & & \\
\hline & M6 & $\begin{array}{l}\text { I do not think industrialization and distorted urbanization are harmful to the } \\
\text { concrete cultural heritage. }\end{array}$ & .66 & & \\
\hline & M7 & I do not think cultural heritage contributes to the advancement of societies. & .64 & & \\
\hline & M8 & $\begin{array}{l}\text { Cultural heritage items can be ignored for investments that will contribute to the } \\
\text { national economy. }\end{array}$ & .62 & & \\
\hline & M9 & I do not think that cultural heritage reflects the historicity. & .46 & & \\
\hline \multirow{12}{*}{ 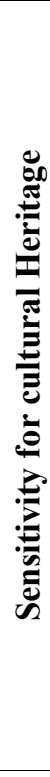 } & M10 & I can identify cultural heritage items. & & .71 & \\
\hline & M11 & If opportunities are given, I will take measures to protect cultural heritage. & & .65 & \\
\hline & M12 & I like to attend the meetings that are about our cultural heritage. & & .63 & \\
\hline & M13 & $\begin{array}{l}\text { I become a member of non-governmental organizations aiming to protect cultural } \\
\text { heritage. }\end{array}$ & & .62 & \\
\hline & M14 & International presentation of our cultural heritage makes me excited. & & .62 & \\
\hline & M15 & $\begin{array}{l}\text { I enjoy reading the documents (books, magazines, brochures, etc.) that reflect the } \\
\text { cultural heritage. }\end{array}$ & & .61 & \\
\hline & M16 & I follow the publications on cultural heritage in the media. & & .58 & \\
\hline & M17 & Cultural heritage is determinant in the formation of national consciousness. & & .52 & \\
\hline & M18 & I like traveling around places that reflect concrete cultural heritage. & & .52 & \\
\hline & M19 & $\begin{array}{l}\text { I think that giving importance to cultural heritage will contribute to the historical } \\
\text { awareness. }\end{array}$ & & .51 & \\
\hline & M20 & I can distinguish between concrete and abstract cultural heritage assets. & & .48 & \\
\hline & M21 & I think that laws on the protection of cultural heritage are inadequate. & & .47 & \\
\hline \multirow{11}{*}{ 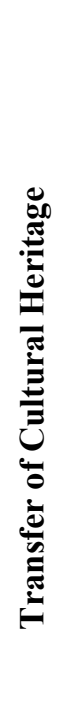 } & M22 & I believe that cultural heritage will bring economic boom. & & & .66 \\
\hline & M23 & Protecting cultural heritage is an important civic duty. & & & .65 \\
\hline & M24 & $\begin{array}{l}\text { For the continuity of society, it is necessary to keep the abstract cultural heritage } \\
\text { alive. }\end{array}$ & & & .65 \\
\hline & M25 & I think cultural heritage serves as a bridge between the past and the future. & & & .63 \\
\hline & M26 & $\begin{array}{l}\text { I believe that the handling of cultural heritage subjects in course content will } \\
\text { improve the historical thinking skills. }\end{array}$ & & & .61 \\
\hline & M27 & I think that cultural heritage reflects the identities of societies. & & & .57 \\
\hline & M28 & The transfer of cultural heritage is important for the future of countries. & & & .54 \\
\hline & M29 & $\begin{array}{l}\text { I think that our country does not give the necessary importance for cultural } \\
\text { heritage. }\end{array}$ & & & .52 \\
\hline & M30 & Conventions on cultural heritage bore me. & & & .49 \\
\hline & M31 & I think that cultural heritage can be associated with all lesson subjects. & & & .46 \\
\hline & M32 & Globalization threatens the preservation of cultural heritage. & & & .45 \\
\hline
\end{tabular}

$\begin{array}{llll}\text { Eigenvalue } & 9.80 & 2.59 & 1.75\end{array}$

Explained Variance $30.63 \quad 8.08 \quad 5.46$ 
As seen in Table 1, items between 1-9 represent the sub-dimension of cultural heritage for society, items between 10-21 represent the sub-dimension of sensitivity to cultural heritages and items between 22-32 represent the sub-dimension of the transfer of cultural heritage. The reliability coefficient for the sub-dimension of cultural heritage for the society was .86 , the reliability coefficient for sub-dimension of sensitivity for cultural heritage was .87 , and the reliability coefficient for the dimension of transfer of cultural heritage was .84 (Akbaba, 2016).

\subsection{Data Collection Process}

The data of the study were collected in two stages. In the first stage, the teacher candidates who would be included in the study were selected with random sampling method through stratified sampling. After selecting the sample, the attitudes towards cultural heritage scale developed by Akbaba (2014) was applied as pre-test to the participants in the spring semester of 2016-2017 academic year. Pre-test data obtained from the participants were analyzed and reported. In the second stage, trips to the places which included the cultural assets in Ağrl province were organized with the participants in the fall semester of 2017-2018 academic year, and the participants were educated about these cultural assets. After the educational trips, the same scale was applied to the teacher candidates as post-test.

\subsection{Analyses of the Data}

In the analysis of the data, SPSS packet software was used and during the organization of the data, the data were reversed in the first sub-dimension as all the data in the first sub-dimension were negative, and colmogorov smirnov, independent sample " $t$ " test, one-factor ANOVA test and dependent " $t$ " test were used in the analyses of the data.

\section{Findings and Interpretation}

This section includes findings related to the data obtained from the attitudes towards cultural heritage scale applied to teacher candidates before and after the educational trip to determine the attitudes and awareness of them towards cultural heritage. The parametric values of the data obtained from the attitudes towards cultural heritage scale are indicated in Table 2.

Table 2. Analysis of the Parametric Values of the Distribution

\begin{tabular}{lcccc}
\hline & $\mathbf{X}$ & \multicolumn{1}{c}{ SS } & Skewness & Kurtosis \\
\hline $\begin{array}{l}\text { Pretest Cultural Heritage } \\
\text { for Society }\end{array}$ & 3.602 & .5626 & .291 & -.739 \\
$\begin{array}{l}\text { Pretest Sensitivity for } \\
\text { cultural Heritage }\end{array}$ & 3.714 & .3858 & .198 & -.424 \\
$\begin{array}{l}\text { Pretest Transfer of } \\
\text { Cultural Heritage }\end{array}$ & 3.850 & .4249 & .011 & .040 \\
$\begin{array}{l}\text { Posttest Cultural Heritage } \\
\text { for Society }\end{array}$ & 4.590 & .5581 & -.271 & .919 \\
$\begin{array}{l}\text { Posttest Sensitivity for } \\
\text { Cultural Heritage }\end{array}$ & 4.216 & .538 & -.310 & 1.06 \\
$\begin{array}{l}\text { Posttest Transfer of } \\
\text { Cultural Heritage }\end{array}$ & 4.234 & .3557 & .322 & .284 \\
\hline
\end{tabular}

When Table 2 is examined, the values of skewness and kurtosis are examined to determine whether the obtained data has a parametric distribution, and it is determined that these values are in a range of -1.5 to 1.5 , so that they show a parametric distribution. The data related to the difference of the sub-dimensions of pretest attitudes and awareness towards cultural heritage according to gender are indicated in Table 3. 
Table 3. Analysis of the Data related to the Difference of the Sub-Dimensions of Pretest Attitudes and Awareness of Teacher Candidates towards Cultural Heritage According to Gender

\begin{tabular}{lcccccc}
\hline & Gender & $\mathbf{n}$ & $\mathbf{X}$ & $\mathbf{S S}$ & $\mathbf{t}$ & $\mathbf{p}$ \\
\hline Cultural Heritage for & Female & 44 & 3,588 &, 560 &,- 251 &, 802 \\
Society & Male & 36 & 3,620 &, 572 & & \\
Sensitivity for & Female & 44 & 3,733 &, 378 &, 468 &, 641 \\
cultural Heritage & Male & 36 & 3,692 &, 398 & & \\
Transfer of Cultural & Female & 44 & 3,880 &, 424 &, 700 &, 486 \\
Heritage & Male & 36 & 3,813 &, 429 & & \\
\hline
\end{tabular}

After analyzing Table 3, it is determined that the difference between the averages of the sub-dimensions of cultural heritage for society, sensitivity for cultural heritage and transfer of cultural heritage as a result of the independent samples t-test which was done to determine whether there is significant difference in the sub-dimensions of attitudes and awareness towards cultural heritage of the teacher candidates according to gender as a result of pretest. The data related to the differentiation values of the sub-dimensions of attitudes and awareness towards cultural heritage of the teacher candidates are indicated in Table 4.

Table 4. Analysis of the Variation Values of the Sub-dimensions of Attitudes and Awareness towards Cultural Heritage of the Teacher Candidates according to Undergraduate Program

\begin{tabular}{|c|c|c|c|c|c|c|c|}
\hline & $\begin{array}{c}\text { Undergraduate } \\
\text { Program }\end{array}$ & $\mathbf{n}$ & $\mathbf{X}$ & SS & $\mathbf{f}$ & $\mathbf{p}$ & $\begin{array}{l}\text { Significant } \\
\text { Difference }\end{array}$ \\
\hline \multirow{6}{*}{$\begin{array}{l}\text { Cultural } \\
\text { Heritage for } \\
\text { Society }\end{array}$} & Turkish-Social & 29 & 4,216 & ,3124 & 28,801 & ,000 & \\
\hline & Sciences & & & & & & A-B \\
\hline & Primary & 26 & 3,646 & 3214 & & & A-C \\
\hline & Education & & & & & & \\
\hline & Fine Arts & 25 & 3,636 & ,3441 & & & \\
\hline & Total & 80 & 3,850 & ,4249 & & & \\
\hline \multirow{5}{*}{$\begin{array}{l}\text { Sensitivity for } \\
\text { cultural } \\
\text { Heritage }\end{array}$} & Social Sciences & 29 & 4,083 & 2597 & 43,168 & ,000 & \\
\hline & Primary & 26 & 3,480 & 2880 & & & A-B \\
\hline & Education & & & & & & A-C \\
\hline & Fine Arts & 25 & 3,530 & 2567 & & & \\
\hline & Total & 80 & 3,714 & ,3858 & & & \\
\hline \multirow{5}{*}{$\begin{array}{l}\text { Transfer of } \\
\text { Cultural } \\
\text { Heritage }\end{array}$} & Social Sciences & 29 & 4,203 & 3199 & 73,740 & ,000 & \\
\hline & Primary & 26 & 3,235 & ,3573 & & & A-B \\
\hline & Education & & & & & & A-C \\
\hline & Fine Arts & 25 & 3,288 & ,3239 & & & \\
\hline & Total & 80 & 3.602 &, 5626 & & & \\
\hline
\end{tabular}

$\mathrm{A}=$ Turkish-Social Sciences, $\mathrm{B}=$ Primary Education, $\mathrm{C}=$ Fine Arts

When the Table 4 is analyzed, it is seen that one-way ANOVA was applied in the analysis of the sub-dimensions of attitudes and awareness towards cultural heritage of the teacher candidates according to the variable of undergraduate program, it was determined that there is a significant difference in cultural heritage for society, sensitivity for cultural heritage and transfer of cultural heritage sub-dimensions.

Bonferroni test was applied to determine among which variables the difference was, and it was determined that there is a significant difference between Turkish-Social Sciences and Primary Education, and between Turkish-Social Sciences and Fine Arts in the undergraduate variable of the sub-dimension of cultural heritage for society. The arithmetic average of the Turkish-Social Sciences Department is 4.216, the arithmetic average of the Primary Education Department is 3.646, and the arithmetic average of the Fine Arts Department is 3.636. According to these results, the undergraduate program is a factor affecting cultural heritage for community and the students in Turkish-Social Sciences department think that the cultural heritage is more for the society than the students in other departments.

According to the results of the "Bonferroni" test, it was determined that there is a significant difference between 
Turkish-Social Sciences and Primary Education and between Turkish-Social Sciences and Fine Arts according to the variance of the sub-dimension of sensitivity for cultural heritage. The arithmetic average of the Turkish-Social Sciences Department is 4,083, the arithmetic average of the Primary Education Department is 3,480, and the arithmetic average of the Fine Arts Department is 3,530. According to these results, the undergraduate program is a factor that affects the pre-test sensitivity for cultural heritage and Turkish-Social Sciences undergraduate students are more sensitive to cultural heritage than other undergraduate students.

According to the results of the "Bonferroni" test, it was determined that there is a significant difference between Turkish-Social Sciences and Primary Education and between Turkish-Social Sciences and Fine Arts according to the undergraduate program variable of the sub-dimension of transfer of cultural heritage. The arithmetic average of the Turkish-Social Sciences Department is 4,203, the arithmetic average of the Primary Education Department is 3,235, and the arithmetic average of the Fine Arts Department is 3,288. The values of the attitudes and awareness sub-dimensions towards pre-test cultural assets according to the class variables are presented in Table 5.

Table 5. Analysis of the Attitude and Awareness Levels of Teacher Candidates for Pre-test Cultural Assets According to Grade Variable

\begin{tabular}{lcccccc}
\hline & Grade & n & X & SS & t & p \\
\hline Cultural Heritage for & 2 & 33 & 3,532 &, 543 &,- 942 &, 349 \\
Society & 3 & 47 & 3,652 &, 576 & & \\
Sensitivity for & 2 & 33 & 3,656 &, 338 & $-1,129$ &, 262 \\
cultural Heritage & 3 & 47 & 3,755 &, 414 & & \\
Transfer of Cultural & 2 & 33 & 3,760 &, 401 & $-1,597$ &, 114 \\
Heritage & 3 & 47 & 3,913 &, 433 & & \\
\hline
\end{tabular}

When the Table 5 is examined, according to the results of t-test applied to determine the values of the sub-dimensions of attitudes and awareness towards cultural heritage of the teacher candidates according to the grade variable, it was determined that there is no significant difference among the averages of cultural heritage for society, sensitivity for cultural heritage and transfer cultural heritage sub-dimensions. Table 6 shows the values of the sub-dimensions of attitudes and awareness of the pre-test cultural assets of the teacher candidates according to the education level of the mother.

Table 6. Analysis of Attitude and Awareness Levels of Teacher Candidates for Pre-test Cultural Assets According to Education Level of Mother

\begin{tabular}{|c|c|c|c|c|c|c|c|}
\hline & $\begin{array}{c}\text { Education Level of } \\
\text { Mother }\end{array}$ & $\mathbf{n}$ & $\mathbf{X}$ & SS & f & $\mathbf{p}$ & $\begin{array}{l}\text { Significant } \\
\text { Difference }\end{array}$ \\
\hline \multirow{5}{*}{$\begin{array}{l}\text { Cultural } \\
\text { Heritage } \\
\text { for Society }\end{array}$} & Illiterate & 32 & 3,376 & 6773 & 3,699 & ,029 & \multirow{4}{*}{ A-B } \\
\hline & Primary School & 25 & 3,804 & 4867 & & & \\
\hline & $\begin{array}{l}\text { Secondary School } \\
\text { and above }\end{array}$ & 23 & 3,607 & ,3635 & & & \\
\hline & Total & 80 & 3,602 & ,5626 & & & \\
\hline & Illiterate & 32 & 3,661 & ,4449 & 5,106 & ,008 & \multirow{4}{*}{$\begin{array}{l}\text { A-B } \\
\text { A-C }\end{array}$} \\
\hline \multirow{4}{*}{$\begin{array}{l}\text { Sensitivity } \\
\text { for } \\
\text { cultural } \\
\text { Heritage }\end{array}$} & Primary School & 25 & 3,903 & 3313 & & & \\
\hline & $\begin{array}{l}\text { Secondary School } \\
\text { and above }\end{array}$ & 23 & 3,883 & ,2706 & & & \\
\hline & Total & 80 & 3,800 & ,3858 & & & \\
\hline & Illiterate & 32 & 3,823 & 4908 & 4,610 & ,013 & \multirow{4}{*}{ None } \\
\hline \multirow{3}{*}{$\begin{array}{l}\text { Transfer } \\
\text { of Cultural } \\
\text { Heritage }\end{array}$} & Primary School & 25 & 4,036 & ,3579 & & & \\
\hline & $\begin{array}{l}\text { Secondary School } \\
\text { and above }\end{array}$ & 23 & 3,783 & ,3159 & & & \\
\hline & Total & 80 & 3,878 & ,4249 & & & \\
\hline
\end{tabular}

$\mathrm{A}=$ Illiterate, $\mathrm{B}=$ Primary School, $\mathrm{C}=$ Secondary School and Above 
When the Table 6 is examined, according to the results of one-way ANOVA applied to determine the values of the sub-dimensions of attitudes and awareness towards cultural heritage of the teacher candidates according to the education level of mother valuable, it was determined that there is no significant difference between cultural heritage for society and sensitivity for cultural heritage sub-dimensions according to the education level of mother, and it was determined that there is no significant difference in the transfer of cultural heritage sub-dimension.

Bonferroni test was applied to determine among which variables the difference was, and it was determined that there is significant difference between illiterate and primary school graduate according to the education level of mother variable of cultural heritage for society. The arithmetic mean of the illiterate level was 3.376, the arithmetic average of the primary school level was 3,804, and the arithmetic average of the secondary school and above level was 3.607. According to these results, education level of mother is a factor affecting pre-test cultural heritage for society, students who have literate mothers think that cultural heritage is more for society than students who have illiterate mothers.

As a result of "Bonferroni" test, it was determined that there is significant difference between illiterate and primary school and between illiterate and secondary school and above according to education level of mother sub-dimension of sensitivity for cultural heritage. The arithmetic average of the illiterate level was 3,661, the arithmetic average of the primary school level was 3,903, and the arithmetic average of the secondary school and above level was 3,883 . According to these results, education level of mother variable is a factor affecting pre-test sensitivity for cultural heritage, and students who have literate mothers are more sensitive to cultural heritage than students who have illiterate. Table 6 indicates the values of the sub-dimensions of attitudes and awareness of the pre-test cultural assets of the teacher candidates according to the education level of the father.

Table 7. Analysis of Attitude and Awareness Levels of Teacher Candidates for Pre-test Cultural Assets According to Education Level of Father

\begin{tabular}{|c|c|c|c|c|c|c|c|}
\hline & $\begin{array}{c}\text { Education } \\
\text { Level of } \\
\text { Father }\end{array}$ & $\mathbf{n}$ & $\mathbf{X}$ & SS & f & $\mathbf{p}$ & $\begin{array}{l}\text { Significant } \\
\text { Difference }\end{array}$ \\
\hline \multirow{6}{*}{$\begin{array}{l}\text { Cultural } \\
\text { Heritage for } \\
\text { Society }\end{array}$} & Illiterate & 25 & 3,480 & ,5139 & 0,011 & 989 & \multirow{6}{*}{ None } \\
\hline & Primary School & 30 & 3,577 & ,5231 & & & \\
\hline & Secondary & 25 & 3,755 & ,6374 & & & \\
\hline & School and & & & & & & \\
\hline & Above & & & & & & \\
\hline & Total & 80 & 3,714 & ,5626 & & & \\
\hline \multirow{6}{*}{$\begin{array}{l}\text { Sensitivity for } \\
\text { cultural } \\
\text { Heritage }\end{array}$} & Illiterate & 25 & 3,666 & 3584 & ,837 & 437 & \multirow{6}{*}{ None } \\
\hline & Primary School & 30 & 3,686 & 4092 & & & \\
\hline & Secondary & 25 & 3,796 & ,3857 & & & \\
\hline & School and & & & & & & \\
\hline & Above & & & & & & \\
\hline & Total & 80 & 3,714 & ,3858 & & & \\
\hline \multirow{6}{*}{$\begin{array}{l}\text { Transfer of } \\
\text { Cultural } \\
\text { Heritage }\end{array}$} & Illiterate & 25 & 3,840 & 3787 & 1,569 & ,215 & \multirow{6}{*}{ None } \\
\hline & Primary School & 30 & 3,857 & ,4534 & & & \\
\hline & Secondary & 25 & 3,850 & ,4498 & & & \\
\hline & School and & & & & & & \\
\hline & Above & & & & & & \\
\hline & Total & 80 & 3,850 & 4249 & & & \\
\hline
\end{tabular}

When the Table 7 is examined, according to the results of one-way ANOVA applied to determine the values of the sub-dimensions of attitudes and awareness towards cultural heritage of the teacher candidates according to the education level of father valuable, and it was determined that there is no significant difference in the sub-dimensions of cultural heritage for society, sensitivity for cultural heritage and the transfer of cultural heritage. The data related to the values of the posttest sub-dimensions of attitudes and awareness towards cultural heritage of the teacher candidates according to gender are indicated in Table 8. 
Table 8. Analysis of the Data related to the Values of the Posttest Sub-Dimensions of Attitudes and Awareness of Teacher Candidates towards Cultural Heritage According to Gender

\begin{tabular}{|c|c|c|c|c|c|c|}
\hline & Gender & $\mathbf{n}$ & $\mathbf{X}$ & SS & $\mathbf{t}$ & $\mathbf{p}$ \\
\hline Cultural Heritage for & Female & 44 & 4,578 & 659 &,- 211 & ,833 \\
\hline Society & Male & 36 & 4,604 & ,409 & & \\
\hline Sensitivity for & Female & 44 & 4,210 & 605 &,- 117 & ,907 \\
\hline cultural Heritage & Male & 36 & 4,224 & ,452 & & \\
\hline Transfer of Cultural & Female & 44 & 4,291 & ,393 & 1,607 &, 112 \\
\hline Heritage & Male & 36 & 4,164 & ,293 & & \\
\hline
\end{tabular}

When the Table 8 is analyzed, as a result of the t-test applied to determine the difference in the sub-dimensions of posttest attitudes and awareness towards cultural assets according to gender, it was determined that the difference between the arithmetic means is not significant in the sub-dimensions of cultural heritage for society, sensitivity for cultural heritage and transfer of cultural heritage The data related to the values of the posttest sub-dimensions of attitudes and awareness towards cultural heritage of the teacher candidates according to the undergraduate program are indicated in Table 4.

Table 9. Analysis of the Values of the Posttest Sub-dimensions of Attitudes and Awareness towards Cultural Heritage of the Teacher Candidates according to Undergraduate Program

\begin{tabular}{|c|c|c|c|c|c|c|c|}
\hline & $\begin{array}{c}\text { Undergraduate } \\
\text { Program }\end{array}$ & $\mathbf{n}$ & $\mathbf{X}$ & SS & $\mathbf{f}$ & $\mathbf{p}$ & $\begin{array}{l}\text { Significant } \\
\text { Difference }\end{array}$ \\
\hline \multirow{7}{*}{$\begin{array}{l}\text { Cultural } \\
\text { Heritage for } \\
\text { Society }\end{array}$} & Turkish-Social & 29 & 4,793 & 2765 & 6,035 & ,004 & \multirow{6}{*}{ A-C } \\
\hline & Sciences & & & & & & \\
\hline & Primary & 26 & 4,641 &, 4231 & & & \\
\hline & Education & & & & & & \\
\hline & Fine Arts & 25 & 4,302 &, 7814 & & & \\
\hline & Total & 80 & 4,590 &, 5581 & & & \\
\hline & Social Sciences & 29 & 4,344 & ,3925 & 1,305 & 277 & \multirow{5}{*}{ None } \\
\hline \multirow{5}{*}{$\begin{array}{l}\text { Sensitivity for } \\
\text { cultural } \\
\text { Heritage }\end{array}$} & Primary & 26 & 4,134 & ,4761 & & & \\
\hline & Education & & & & & & \\
\hline & Fine Arts & 25 & 4,153 & ,7126 & & & \\
\hline & Total & 80 & 4,216 & ,5386 & & & \\
\hline & Social Sciences & 29 & 4,250 & ,3389 & 053 & ,949 & \multirow{5}{*}{ None } \\
\hline \multirow{4}{*}{$\begin{array}{l}\text { Transfer of } \\
\text { Cultural } \\
\text { Heritage }\end{array}$} & Primary & 26 & 4,220 & ,4115 & & & \\
\hline & Education & & & & & & \\
\hline & Fine Arts & 25 & 4,229 & ,3247 & & & \\
\hline & Total & 80 & 4,234 & ,3557 & & & \\
\hline
\end{tabular}

$\mathrm{A}=$ Turkish-Social Sciences, $\mathrm{B}=$ Primary Education, $\mathrm{C}=$ Fine Arts

After analyzing Table 9, it is seen that one-way ANOVA was applied to determine the difference in the posttest sub-dimension of attitudes and awareness towards cultural assets according to undergraduate program, and it was determined that the difference is significant in the sub-dimension of cultural heritage for Society according to undergraduate program.

Bonferroni test was applied to determine among which variables the difference was, and it was determined that there is significant difference between Turkish-Social Sciences and Fine Arts according to the undergraduate program variable of the sub-dimension of Cultural Heritage for Society. The arithmetic average of the Turkish-Social Sciences Department is 4.793, the arithmetic average of the Basic Education Department is 4.641, and the arithmetic average of the Fine Arts Department is 4.302. According to these results, the undergraduate program is a factor affecting cultural heritage for the Society and Turkish-Social Sciences students think that the cultural heritage is more for the society than the other department students. The values of the attitudes and awareness sub-dimensions towards the posttest cultural assets of teacher candidates are indicated in Table 10. 
Table 10. Analysis of the Values related to the Grade Variable of the Posttest Attitudes and Awareness towards Cultural Assets of the Teacher Candidates

\begin{tabular}{lcccccc}
\hline & Grade & n & X & SS & t & p \\
\hline Cultural Heritage for & 2 & 33 & 4,636 &, 4037 &, 616 &, 539 \\
Society & 3 & 47 & 4,557 &, 6472 & & \\
Sensitivity for & 2 & 33 & 4,247 &, 4811 &, 426 &, 671 \\
cultural Heritage & 3 & 47 & 4,195 &, 5797 & & \\
Transfer of Cultural & 2 & 33 & 4,242 &, 3907 &, 174 &, 862 \\
Heritage & 3 & 47 & 4,228 &, 3331 & & \\
\hline
\end{tabular}

After analyzing the Table 10, as a result of the independent samples $t$ test conducted to determine the difference according to the grade variable of the sub-dimensions of attitudes and awareness towards cultural assets of the teacher candidates, it was determined that the difference between the averages of the sub-dimensions of cultural heritage for society, sensitiveness towards cultural heritage and transfer of cultural heritage is not significant. Table 11 indicates the data related to values obtained as a result of the analysis the education level of mother variable of the sub-dimensions of attitudes and awareness towards cultural assets of the teacher candidates.

Table 11. Analysis of the Posttest Attitudes and Awareness towards Cultural Assets of Teacher Candidates According to Education Level of Mother Variable

\begin{tabular}{|c|c|c|c|c|c|c|c|}
\hline & $\begin{array}{l}\text { Education } \\
\text { Level of } \\
\text { Mother }\end{array}$ & n & $\mathbf{X}$ & SS & f & $\mathbf{p}$ & $\begin{array}{l}\text { Significant } \\
\text { difference }\end{array}$ \\
\hline \multirow{7}{*}{$\begin{array}{l}\text { Cultural } \\
\text { Heritage for } \\
\text { Society }\end{array}$} & Illiterate & 32 & 4,614 & ,4298 & ,696 &, 502 & \\
\hline & Primary School & 25 & 4,662 & 6785 & & & None \\
\hline & Secondary & 23 & 4,478 & 5797 & & & \\
\hline & School and & & & & & & \\
\hline & Above & & & & & & \\
\hline & Total & 80 & 4,590 & 5581 & & & \\
\hline & Illiterate & 32 & 4,276 & ,3928 & 2,227 & ,115 & \\
\hline \multirow{5}{*}{$\begin{array}{l}\text { Sensitivity for } \\
\text { cultural } \\
\text { Heritage }\end{array}$} & Primary School & 25 & 4,332 & 4833 & & & None \\
\hline & Secondary & 23 & 4,021 & ,7160 & & & \\
\hline & School and & & & & & & \\
\hline & $\begin{array}{c}\text { Above } \\
\text { Total }\end{array}$ & 80 & 4,216 & ,5386 & & & \\
\hline & Illiterate & 32 & 4,252 & ,3499 & ,084 &, 920 & \\
\hline \multirow{5}{*}{$\begin{array}{l}\text { Transfer of } \\
\text { Cultural } \\
\text { Heritage }\end{array}$} & Primary School & 25 & 4,229 & ,3785 & & & None \\
\hline & Secondary & 23 & 4,213 & 3527 & & & \\
\hline & School and & & & & & & \\
\hline & Above & & & & & & \\
\hline & Total & 80 & 4,234 & 3557 & & & \\
\hline
\end{tabular}

When the Table 11 is examined, it is seen that independent samples $t$ test was applied to determine the difference in the sub-dimensions of attitudes and awareness towards cultural assets of the teacher candidates, and as a result of it, it was determined that there is no significant difference between the averages for the sub-dimensions of cultural heritage for society, sensitivity for cultural heritage and transfer of cultural heritage. Table 12 indicates the data related to values obtained as a result of the analysis the education level of father variable of the sub-dimensions of attitudes and awareness towards cultural assets of the teacher candidates. 
Table 12. Analysis of the Posttest Attitudes and Awareness towards Cultural Assets of Teacher Candidates According to Education Level of Father Variable

\begin{tabular}{|c|c|c|c|c|c|c|c|}
\hline & $\begin{array}{c}\text { Education } \\
\text { Level of } \\
\text { Father } \\
\end{array}$ & $\mathbf{n}$ & $\mathbf{X}$ & SS & f & $\mathbf{p}$ & $\begin{array}{l}\text { Significant } \\
\text { difference }\end{array}$ \\
\hline \multirow{6}{*}{$\begin{array}{l}\text { Cultural } \\
\text { Heritage for } \\
\text { Society }\end{array}$} & Illiterate & 25 & 4,644 & ,3239 & 0,168 & ,845 & \\
\hline & Primary School & 30 & 4,563 & 6941 & & & None \\
\hline & Secondary & 25 & 4,568 &, 5776 & & & \\
\hline & $\begin{array}{c}\text { School and } \\
\text { Above }\end{array}$ & & & & & & \\
\hline & Total & 80 & 4,590 & ,5581 & & & \\
\hline & Illiterate & 25 & 4,240 & ,3026 & , 198 &, 821 & \\
\hline \multirow{5}{*}{$\begin{array}{l}\text { Sensitivity for } \\
\text { cultural } \\
\text { Heritage }\end{array}$} & Primary School & 30 & 4,244 & ,4946 & & & None \\
\hline & Secondary & 25 & 4,160 &, 7503 & & & \\
\hline & $\begin{array}{c}\text { School and } \\
\text { Above }\end{array}$ & & & & & & \\
\hline & Total & 80 & 4,216 & ,5386 & & & \\
\hline & Illiterate & 25 & 4,330 & ,3952 & 2,256 & ,112 & \\
\hline \multirow{4}{*}{$\begin{array}{l}\text { Transfer of } \\
\text { Cultural } \\
\text { Heritage }\end{array}$} & Primary School & 30 & 4,133 & ,3164 & & & None \\
\hline & Secondary & 25 & 4,258 & ,3408 & & & \\
\hline & $\begin{array}{c}\text { School and } \\
\text { Above }\end{array}$ & & & & & & \\
\hline & Total & 80 & 4,234 & ,3557 & & & \\
\hline
\end{tabular}

When the Table 12 is examined, it is seen that one-way ANOVA was applied to determine the difference in the sub-dimensions of attitudes and awareness towards cultural assets of the teacher candidates according to education level of father variable, and as a result of it, it was determined that there is no significant difference between the averages for the sub-dimensions of cultural heritage for society, sensitivity for cultural heritage and transfer of cultural heritage in terms of education level of father variable. The data related to the effect of the organized educational trip on the views of the teacher candidates about cultural heritage for society sub-dimension are indicated in Table 13.

Table 13. Analysis of the Effect of the Educational Trip on the Views of the Teacher Candidates about Cultural Heritage for Society

\begin{tabular}{cccccc}
\hline & $\mathbf{n}$ & $\mathbf{X}$ & SS & t & p \\
\hline Pretest & 80 & 3.602 &, 5626 & 13,872 &, 000 \\
Posttest & 80 & 4.590 &, 5581 & & \\
\hline
\end{tabular}

When the Table 13 is examined, it is seen that the posttest scores of the teacher candidates differ from their pretest scores in a significant level as a result of the dependent samples t test which was conducted to determine the effect of the experimental process. After analyzing the $\mathrm{t}$ value in Table 13, it is seen that $\mathrm{t}=13,872$ and $\mathrm{p}=.000$, the pretest arithmetic mean of the student is 3.602 and posttest arithmetic mean of the student is 4.590 . According to this result, it can be said that the organized educational trip affected the views of the teacher candidates positively about the cultural heritage for society. The data related to the effect of the organized educational trip on the views of the teacher candidates about sensitivity for cultural heritage sub-dimension are indicated in Table 14.

Table 14. Analysis of the Effect of the Educational Trip on the Views of the Teacher Candidates about Sensitivity for cultural Heritage

\begin{tabular}{cccccc}
\hline & n & X & SS & t & p \\
\hline Pretest & 80 & 3.714 &, 3858 & 7,488 &, 000 \\
Posttest & 80 & 4.216 &, 5386 & & \\
\hline
\end{tabular}


After analyzing the Table 14, it can be seen that the posttest scores of the teacher candidates differ from their pretest scores in a significant level as a result of the dependent samples $t$ test which was conducted to determine the effect of the experimental process. When the $t$ value in Table 14 is examined, it is seen that $t=7.488$ and $p=.000$, and pretest arithmetic mean of the student is 3.714 and the posttest arithmetic mean is 4.216 . According to this, it can be said that the organized educational trip was effective in increasing the sensitivity of the teacher candidates towards the cultural assets. The data related to the effect of the organized educational trip on the views of the teacher candidates about transfer of cultural heritage sub-dimension are indicated in Table 14.

Table 14. Analysis of the Effect of the Educational Trip on the Views of the Teacher Candidates about Transfer of Cultural Heritage

\begin{tabular}{cccccc}
\hline & $\mathbf{n}$ & $\mathbf{X}$ & SS & $\mathbf{t}$ & $\mathbf{p}$ \\
\hline Pretest & 80 & 3.850 &, 4249 & 6,797 &, 000 \\
Posttest & 80 & 4.234 &, 3557 & & \\
\hline
\end{tabular}

After analyzing the Table 15, it can be seen that the posttest scores of the teacher candidates differ from their pretest scores in a significant level as a result of the dependent samples $t$ test which was conducted to determine the effect of the experimental process. When the $t$ value in Table 15 is examined, it is seen that $\mathrm{t}=6.797$ and $\mathrm{p}=.000$, and pretest arithmetic mean of the student is 3.850 and the posttest arithmetic mean is 4.234 . According to this, it can be said that the organized educational trip affected positively the views of the teacher candidates about the transfer of the cultural heritage.

\section{Conclusions}

In this study, which was conducted to determine the attitudes and awareness of teacher candidates towards cultural assets, the cultural heritage attitude scale was applied to teacher candidates as pre-test and post-test before and after the educational trip and the following results were obtained.

According to pre-test and post-test results of the attitudes and awareness of the teacher candidates towards cultural assets according to gender, it was determined that there is no significant difference in terms of cultural heritage for society, sensitivity for cultural heritage and transfer of cultural heritage sub-dimensions. According to this result, it can be said that the gender variable does not have influence on the attitudes and awareness of teacher candidates towards cultural assets. This result is similar to the study by Arrkan (2012) on $7^{\text {th }}$ grade students and showing that the gender factor in students' attitudes towards cultural assets is not determinative. A similar result is seen in the study of Alkış and Oğuzoğlu (2005). In their study conducted in Bursa sample, they showed that the attitudes of primary and secondary school students towards cultural assets are not at the expected level. In the study conducted by Sidekli and Karaca (2013), it was determined that the attitudes of the teacher candidates regarding the usage of the local cultural heritage items in social studies education did not differ according to gender. Contrary to these studies, it was emphasized that the attitudes of men towards national values were more positive than those of girls in the study of Çetin (2013) studying the attitudes of teacher candidates towards national values. In the study on historical and cultural heritage conducted in Buca by Gümüş and Adanalı (2011), it was determined that female students have a more positive attitude towards cultural heritage than male students. A similar result has been found in the study of the social studies teacher candidates by Keçe (2015) about the historical and cultural tourism values of Ankara and in the study by Çetin and Gürgil (2014) about Bartın's natural and cultural tourism values.

According to the pre-test result of the attitudes and awareness of the cultural assets, it was found that there is significant difference in terms of the cultural heritage for society, sensitivity for cultural heritage and transfer of cultural heritage sub-dimensions according to the undergraduate program. According to this difference, the teacher candidates in Turkish-Social Sciences undergraduate program are more sensitive for cultural assets than the teacher candidates in other undergraduate programs. As a result of the last test applied to teacher candidates after the educational trip, only a significant difference was found in the cultural heritage for the society sub-dimension. According to this difference, the teacher candidates in the Turkish-Social Sciences undergraduate program were found to have higher attitudes and awareness towards cultural assets than the teacher candidates in other undergraduate programs. Zor and Karip (2014) reached the conclusion in their study which analyzed the lessons taught in secondary schools in terms of raising cultural heritage awareness that visual arts and social studies lessons are the the most effective lessons to raise awareness for the cultural assets, taking into account the achievements of 
the most effective lessons. It can be said that the results of these two studies support each other. In the study conducted by Çetin and Gürgil (2014), it was determined that the undergraduate program differentiates the attitudes of the teacher candidates towards the natural and cultural values and that the teacher candidates who are in the science undergraduate program have a more positive attitude towards the natural and cultural values. Contrary to these studies, it has been determined by Sidekli and Karaca (2013) that the attitudes of teacher candidates towards cultural heritage regarding the use of local cultural heritage items in social studies education do not differ according to the undergraduate program in which they are studying.

As a result of the last test, no significant difference was found in the sub-dimensions of sensitivity for cultural heritage and transfer of cultural heritage. This result, which is obtained as a result of the last test, may be the result of educational trip and education given to all teacher candidates about cultural assets.

According to pre-test-post test results applied to determine the attitudes and awareness of the teacher candidates towards cultural assets according to the grade variable, it was found that there is no significant difference in terms of cultural heritage for society, sensitivity for cultural heritage and transfer of cultural heritage sub-dimensions. According to this result, it can be said that the grade variable has no effect on teacher candidates' attitudes and awareness towards cultural assets. In contrast to this study, it is determined in the study conducted by Sidekli and Karaca (2013) that the social studies teacher candidates in the $4^{\text {th }}$ grade have a more positive attitude towards cultural heritage than the $1^{\text {st }}$ grade students. In the study conducted by Gümüş and Adanalı (2011), it was determined that third grade students have a more positive attitude towards cultural heritage than second grade students. Similarly, in the study conducted by Keçe (2015), it was found that third grade students have higher attitudes than other class levels.

According to the pre-test results of the attitudes and awareness of the teacher candidates about the cultural assets according to the education level of mother, it was determined that there is a significant difference in terms of the sub-dimensions of sensitivity for cultural heritage and cultural heritage for society. According to this difference, it was determined that the attitudes and awareness of teacher candidates towards cultural assets increased in parallel with the increase of education level of mother. There was no significant difference in the transfer of cultural heritage sub-dimension. according to the posttest result, it was determined that the education level of mother did not affect attitudes and awareness levels of teacher candidates towards cultural assets in terms of cultural heritage for society, sensitivity for cultural heritage and transfer of cultural heritage sub-dimensions. This result, which is obtained as a result of posttest, may be due to the educational trip and the training given to teacher candidates about the cultural assets. In the study by Çetin (2013) which analyzed the attitudes of the teacher candidates towards the national values, it was determined that there is no difference between the attitudes of the teacher candidates towards the national values according to the education level of mother. Similarly, in the study conducted by Keçe (2015), it was concluded that the education level of mother did not affect teacher candidates' interest and awareness about the historical and cultural values.

According to the pre-test-posttest results of the attitudes and awareness of the teacher candidates about the cultural assets according to the education level of father, it was determined that there is no significant difference in terms of cultural heritage for the society, sensitivity for cultural heritage and transfer of cultural heritage sub-dimensions. According to this result, it can be said that the education level of father variable does not influence the attitudes and awareness of teacher candidates towards cultural assets. Similar results were found in the study conducted by Çetin (2013). Contrary to these studies, in the study conducted by Keçe (2015), it was determined that the educational status of the father affects positively the interest and awareness of the of the teacher candidates about historical and cultural values. According to this study, as the educational level of the father increases, the interest and awareness of the teacher candidates towards the historical and cultural values increases.

As a result of the analyzes made to determine the effect of the experimental process applied to the attitudes and awareness of the teacher candidates towards the cultural assets, it was determined that there is significant difference between the pretest and posttest results in terms of the cultural heritage for society, sensitivity for cultural heritage and transfer of cultural heritage sub-dimensions. According to this result; it can be said that the organized educational trip is effective in developing positive attitudes and awareness in teacher candidates towards the cultural assets. It is clear that in order to protect and evaluate the historical environment in a healthy way, the policies and activities applied in this area need to be taken away from the economic basis and handled with social, cultural and educational dimensions (Çırak 2010). Similarly, in the study conducted by Güler (2011) to determine the effect of a planned museum trips on the attitude of the students, it was also emphasized that the students in the experimental group had a more positive attitude than the students in the control group. In the study by Donmez and Yeşilbursa 
(2014) on the effect of cultural heritage training on the attitudes of students towards concrete cultural heritage, it was found that after cultural heritage training, students developed a positive attitude towards concrete cultural heritage. Therefore, it can be said that these studies support each other in terms of the results they achieved.

\section{Recommendations}

It was determined that the attitudes and awareness of teacher candidates towards cultural assets increased as a result of the educational trip. With this educational trip, teacher candidates were taken to areas where cultural assets are located, and they were provided to see these assets and learn about them. Considering that the attitudes and awareness of teacher candidates towards cultural assets are increased as a result of this process, it is thought that it would be useful to organize such educational trips as much as possible within the scope of educational activities.

Financial resources are needed to organize such educational trips within the scope of educational activities. This study was carried out with the support of Scientific Research Project Unit of İbrahim Çeçen University of Ağrı. Therefore, considering the effectiveness of the training, it is considered that it would be beneficial to support such studies for a higher quality education activity.

Cultural assets are important sources of heritage that enhance the areas they are in and have a positive contribution to them in both material and spiritual terms. Protecting these assets and transferring them to the future depends on the educational activities to be carried out for people. Teacher candidates are the people who will train future generations. Therefore, it will undoubtedly be an important step to train teacher candidates who will train the future generations in terms of protecting and preserving these resources. Within this scope, it is considered that including lessons in protecting and maintaining cultural assets in the undergraduate programs will contribute to the protection and survival of these assets.

\section{References}

Ahunbay, Z. (2009). Tarihi Çevre Koruma ve Restorasyon. İstanbul: Yem Yayın.

Akbaba, B. (2014). Developing Attitude Towards Cultural Heritage Scale: A Validity and Reliability Study. Educational Research and Reviews, 9(20), 1046-1054. https://doi.org/10.5897/ERR2014.1908

Alkış, S., \& Oğuzoğlu, Y. (2005). İlköğretim öğrencilerinin tarihi çevre bilincinin değerlendirilmesi, Uludă̆ Üniversitesi Ë̆itim Fakültesi Dergisi, 18(1), 23-46.

Alkış, Ş., \& Oğuzoğlu, Y. (2005). Ülkemiz koşullarında tarihi çevre eğitiminin önemini ve gerekliliğini artıran nedenler. Uludağ Üniversitesi Eğitim Fakültesi Dergisi, 18(2), 347-361.

Altınörs, A. (2005). Koruma Çalı̧̧malarında Toplumsal Katılımın Sağlanması Sürecinde Tarih Bilincinin Gelişsirilmesinin Önemi', Kent Planlama ve Koruma Etkinlikleri I Koruma Sempozyumu Diyarbakır, 41-52.

Altınörs, A. (2010). Korumanın Toplumsal ve Kültürel Boyutu Neden Önemli? Biz Nasıl Bakıyoruz?, Planlama 2010/1, s. 29-37, www.spo.org.tr adresinden 27 Eylül 2011 tarihinde alınmıştır.

Arıkan, İ., \& Doğan, Y. (2012). İlköğretim 7. Sınıf Öğrencilerinin Kültürel Miras İle İlgili Başarı Düzeyleri ve Tutumlarının Bazı Değişkenlerle İncelenmesi (Adıyaman Örneği), Adıyaman Üniversitesi Sosyal Bilimler Enstitüsü Dergisi, 6(15), 29-68.

Asatekin, G. (2004). Kültür ve Doğa Varlıklarımız Neyi Niçin Nasıl Korumalıyız. Ankara: DÖSİMM Basımevi.

Asatekin, N. G. (2005). 'İlköğretim II. Kademe Öğrencilerinde Restorasyon/Koruma Bilincinin Niteliğinin Saptanması Konusunda Ders Kitabının Rolü’, 60. Yaşında Sinan Genim’e Armağan Makaleler, Ege Yayınları, İstanbul. s. 50-69.

Bilgili. A. E. (2010). Şehir ve Kültür, Eşsizliğin Doruk Noktası: İstanbul, Şehir ve Kültür: İstanbul, İstanbul: Ebru Matbaacilık.

Büyüköztürk, Ş., Çakmak, E. K., Akgün, Ö. E., Karadeniz, Ş., \& Demirel, F. (2014). Bilimsel Araştırma Yöntemleri. (18.Bask1). Ankara: Pegem Akademi.

Copeland, T. (2006). European democratic citizenship, heritage education and identity. 2005 Year of Citizenship through Education. Council of Europe.

Curtis, R., \& Seymour, C. (2004). Louisiana heritage education program and heritage in the classroom: children's attitudes toward cultural heritage. Journal of Social Studies Research, 28(2), 20-24. 
Çetin, Ş. (2013). Öğretmen Adaylarının Milli Değerlerin Öğretimine Yönelik Tutumlarının Farklı Değişkenler Açısından İncelenmesi. Turkish Studies, 8(8), 1733-1743. https://doi.org/10.7827/TurkishStudies.5277

Çetin, T., \& Gürgil, F. (2014). Üniversite Öğrencilerinin Bartın'ın Doğal ve Kültürel Turizm Değerlerine Yönelik Farkındalıkları. Uşak Üniversitesi Sosyal Bilimler Dergisi, 7(4), 255-274.

Çırak, A.A. (2010). Korumanın Toplumsal ve Kültürel Boyutu Neden Önemli? Biz nasıl Bakıyoruz?, Planlama, 1, 29-37.

Dönmez, C., \& Yeşilbursa, C. C. (2014). Kültürel Miras Eğitiminin Öğrencilerin Somut Kültürel Mirasa Yönelik Tutumlarına Etkisi. Illköğretim Online, 13(2), 425 - 442.

Güler, A. (2011). Planlı Bir Müze Gezisinin İlköğretim Öğrencilerinin Tutumuna Etkisi. İlköğretim Online, 10(1), 169-179.

Gümüş, N., \& Adanalı, R. (2011). Buca'da (İzmir) Tarihi ve Kültürel Mirasa Yönelik Ortaöğretim Öğrencilerinin Tutum ve Davranışları. Buca Eğitim Fakültesi Dergisi, 30, 87-102.

Henson, D. (2004). Archaeology in Schools. In D. Henson, P. Stone and M. Corbishley (Eds.), Education and the historic environment (pp. 23-32). New York: Routledge.

Hunter, K. (1988). Heritage education in the social studies. Retrieved 28 Aralı 2015 from http://www.ericdigests.org/pre-929/heritage.htm

Karip, F. (2016). Görsel sanatlar ögretmen adaylarının kültür ve doğa varlıklarına yönelik bilişsel yapıları, Cumhuriyetin Işs̆ğında Yüksek Öğretimde Sanat Eğitimi Uluslararası Sempozyumu, Gazi Üniversitesi, 23-25 Kasım 2016, Ankara.

Keçe, M. (2015). Sosyal Bilgiler Öğretmen Adaylarının Ankara’nın Tarihi ve Kültürel Turizm Değerlerine Yönelik İlgi ve Farkındalıkları. Ahi Evran Üniversitesi Kırşehir Eğitim Fakültesi Dergisi (KEFAD), 16(1), 131-149.

Özdemir, M.Z.D. (2005). Türkiye'de Kültürel Mirasın Korunmasına Kısa Bir Bakış. Planlama, 2005(1), 20-25.

Patrick, J.J. (1988). Historic preservation and school curriculum. Paper presented at the symposium on Heritage Education (Washington, DC, May 11), ERIC ED 300289.

Robson, C. (2015). Bilimsel Araştırma Yöntemleri, Gerçek Dünya Araştırması. (Çev. Edt. Ş. Çınkır ve N. Demirkasımoğlu) (1. Baskı), Ankara: Anı Yayınc1lık. (Eserin Orijinali 1993’te yayımlandı).

Sidekli, S., \& Karaca, L. (2013). Sosyal Bilgiler Öğretiminde Yerel, Kültürel Miras Öğelerinin Kullanımına İlişkin Öğretmen Adayı Görüşleri. Gaziosmanpaşa Bilimsel Araştırma Dergisi, 5, 20-38.

Sönmez, V., \& Alacapınar, F. G. (2014). Örneklendirilmiş Bilimsel Araştırma Yöntemleri. (3rd. Baskı.). Ankara: Anı Yayıncilik.

$\begin{array}{llll}\text { TDK(1932). } & \text { Retrieved } & 08.07 .2018 & \text { from }\end{array}$ http://www.tdk.gov.tr/index.php?option=com_bts\&view=bts\&kategoril=veritbn\&kelimesec $=214144$

Zor, A., \& Karip, F. (2014). İlköğretim İkinci Kademede Okutulan Derslerin Kültürel Mirası Korumada Amaçlarına Uygunluğunun Değerlendirilmesi. Gazi Sanat ve Tasarım dergisi, 14, 147-162. 